INVITED 2011 CARROLL D. Clark LeCTURER

AT THE

UNIVERSITY OF KANSAS 



\title{
INTERVIEW WITH LANE KENWORTHY
}

\author{
INTERVIEW CONDUCTED BY: \\ CARRIE WENDELL-HUMMEL \\ University of Kansas \\ ANDREA GOMEZ-CERVANTES \\ University of Kansas
}

Dr. Lane Kenworthy is Professor of Sociology and Yankelovich Chair in Social Thought at the University of California-San Diego and Professor of Sociology and Political Science at The University of Arizona. His work focuses on the causes and consequences of living standards, poverty, inequality, mobility, employment, economic growth, social policy, taxes, public opinion, and politics in the United States and other affluent countries. Dr. Kenworthy joined us to talk about public sociology, income inequality, and voting.

CARRIE: Thank you for allowing us to do this interview and to publish it in STAR.

You've written articles for journals that aim to present academic research in more readable, down-to-earth format. You've also done radio interviews and a blog called "Consider the Evidence." Could you talk more about these public sociology endeavors? Why do you think it's important to do this?

KENWORTHY: I do it because many of the issues I study and the research questions I try to answer are relevant to policy debates and likely to be of interest to the public. That's not true for every social scientist, however, so I don't think it's vital for academics to do this. I embrace public sociology, but it's not something all sociologists should feel compelled to do.

CARRIE: Okay. Is there any particular advice you might give to someone else interested in doing that? 
KENWORTHY: My blog has been very helpful. A blog allows you to write for a popular audience instantly and often. Most blogs don't reach a wide audience. But some do, and others get their posts picked up by an aggregator-a person or website that pulls together what they see as best on the web in the area they focus on-or on social media. Even if the audience is small, writing blog posts gives you a chance to clarify your thinking and improve your writing. For most of us, writing is a difficult skill, so the more practice you get, the better. And you can publish your thoughts in real time, instead of having to wait weeks or months or years to get into print.

ANDREA: You have conducted a lot of research on income inequality across affluent nations. In this line of research the U.S. stands out as an outlier in terms of high-income inequality and meager social welfare options. How do you think the racial make up of the U.S. has led the country to be so different in this regard?

KENWORTHY: One view is that race is the crux of what separates the United States from most western European countries in terms of the size and scope of our public safety net. The idea is that racial difference-including perceptions that most poor people are nonwhite-makes many Americans less receptive to the notion of a generous welfare state. I do think that's part of the story.

But I don't see public opinion as having been a major determinant of the types of social programs put in place. In my view, the creation and expansion of social programs has had more to do with the strength of organized interest groups and the composition of political parties. It's not an accident that the New Deal was put in place in the 1930s when the economy was falling apart, labor was on the rise, unions were organizing, and the Democrats had the presidency and large majorities in both houses of Congress. It's not that the American public was pushing strongly for the creation of social security or unemployment insurance. There was support, but I think what really drove it was a moment in the politics. So policies get enacted at opportune moments, and if they're effective public opinion comes around and supports them and makes it harder to take them away. The same is true if we want to understand differences across countries. It's not 
that in the 1930s Swedes were much more in favor of generous encompassing social programs than Americans were. The key difference is that unions were a lot stronger and Sweden's left party had a different orientation than our Democrats. Now, many years later, we observe big differences in public opinion between Swedes and Americans, but those are more the result than the cause of the differences in social programs.

Another way race may have mattered has to do with the strength of the union movement. There is a very strong association across rich countries between the organization and the centralization of unions and the generosity of social programs. Here in the United States the racial divide was a significant obstacle to union organizing.

Finally, race had another indirect effect via the shape of the political parties. The Democratic Party for a long time was an odd combination of liberals in the northern and western parts of the country and conservatives in the south. This was a legacy of the Civil War and race. When the opportunity arose in the 1930s to put in place a bunch of important pillars of the public safety net, a lot of stuff got done. It was certainly a progressive moment in our history. But the shape and generosity of the programs were limited because of the southern Democrats. The same sort of thing happened in the 1960s, the next stage of major welfare state expansion.

CARRIE: This question comes from a student who couldn't be here today. His name is Kevin McCannon, and he cited you often in his most recent area exam. His question is in reference to a 2010 article you wrote with Andrew Gelman and Yu-Sung Su. Kevin asks: in a recent article you and your fellow researchers found no clear relation between class-based voting and income inequality. However, in this article your analyses are for years prior to the Great Recession, the recent national debt debate, and the newest proposal from the White House to increase taxes on millionaires - a proposal Republicans are labeling "class warfare." Do you think that in this new context, one in which inequalities are seemingly more transparent, income inequalities may be more of a factor in partisan voting than before? 
KENWORTHY: That's possible, though we won't have the data to look at this for a while. On the other hand, historically the public opinion survey data suggest that while Americans think there's too much income inequality, it's way down the list of their top concerns. They're much more interested in healthy economic growth and in income security. They're interested in programs that do happen to reduce inequality but in their view are far more useful for providing security and also opportunity. So although it wouldn't surprise me if inequality, at least for this period and perhaps for a little while afterwards, does have more of an effect on partisan voting, it also wouldn't surprise me if it doesn't.

CARRIE: What social and economic policies do you think are needed right now in the U.S. to return to more just levels of income inequality? And which do you think are actually feasible in the current political climate?

KENWORTHY: The feasibility part is very difficult, because Republicans in Congress have settled on a strategy of simply opposing everything that the Obama administration and Democrats want to do. The 2009 economic stimulus package included some things that will reduce income inequality a little, like a small increase in the Earned Income Tax Credit. The 2010 healthcare reform includes a higher tax on the richest to help fund Medicare, but otherwise it won't have much impact on measured income inequality, because the value of healthcare isn't included in the standard income data.

What sorts of things could be done in the absence of intense opposition from Republicans? There are two aspects of income inequality in the U.S. over the last generation. One is the rich - the top $1 \%$ - pulling away from everybody else. The other is widening inequality within the bottom $99 \%$, the defining feature of which has been slow income growth for households in the middle and below.

One common proposal is a salary cap for people at the top. But there are practical difficulties. For CEOs, a lot of pay comes from stock options, which aren't as easy to limit as salary. And they might just shift compensation into nonmonetary forms; the firm can buy the CEO vacation homes, pay for their kids' college 
tuition, buy them a private jet to fly around, and so on. There's also the problem of how to justify a cap on pay for CEOs but not for people in finance, like hedge fund managers, or for entrepreneurs and athletes and entertainers. A better strategy, I'd say, is to increase taxation of those at the top. My preference would be to go back to late 1990s levels, see how that works, and then maybe go a little higher-do it incrementally, a gradual trialand-error-type approach.

To address slow income growth for households in the middle and below, I favor a couple of things. One is expansion of government services - early education, access to low-cost college, truly universal healthcare, job training and placement assistance, personalized care for those with special needs, access to broadband, public transportation, improved roads and bike paths, parks and greenspace, and more. The value of services doesn't show up as income, so this doesn't reduce measured income inequality, but it does reduce inequality of living standards.

For actual incomes, the minimum wage and the Earned Income Tax Credit are key. Many on the left would like to see stronger unions. Historically, unions have been a major force for improving wages and household incomes in the U.S., and their comparative weakness here is a big part of the reason why the U.S. wage patterns and welfare state generosity differ from Western European countries. But it's very unlikely that unions can regain anything like the strength they used to have, so we have to look to the minimum wage and the Earned Income Tax Credit. I'd like to see the EITC expanded into the middle class.

CARRIE: We just have one more question. This also comes from Kevin and in reference to that 2010 article. He asks: if income inequality is not a clear predictor of partisan voting, where should sociologists be looking for a stronger relationship? You mention education and religion in your 2010 article. Could you elaborate on that?

KENWORTHY: The 2010 article had a specific finding about the effect of income inequality on partisan voting. Poor Americans are much more likely to vote Democratic than Republican. Income is more important than social issues as a predictor of voting behavior 
of poor versus rich Americans. So we asked: Has the gap in party preference between the poor and the rich widened even further as their incomes have grown further apart? Has rising income inequality made the rich even more likely to vote Republican and the poor even more likely to vote Democratic? We don't find much evidence that that has been the case.

We say part of the reason for this is education and part of it is religion. But I want to emphasize that income remains a very good predictor of which party a person votes for. It's just that income's influence doesn't seem to have increased as the gap in incomes has widened.

ANDREA: Do you think it has to do as well with the political campaign - how, for example, Obama's campaign was aiming towards Latinos and he would talk to Latino artists, who then would campaign for him? Do you think this has an influence at all?

KENWORTHY: I think its effect is relatively small. The policies that the parties espouse and enact tend to have a much bigger impact. 